\title{
Leaving Quietly? A Quantitative Study of Retirement Rituals and How They Affect Life Satisfaction
}

\author{
Levi van den Bogaard ${ }^{1,2}$
}

\author{
1. Department of Sociology, University of Amsterdam, Amsterdam, Netherlands \\ 2. Netherlands Interdisciplinary Demographic Institute, The Hague, Netherlands
}

\begin{abstract}
This study quantitatively explores the understudied topic of retirement rituals, what factors influence them, and how the experience of such rites of passage may affect postretirement satisfaction with life (SWL). Various regression techniques are applied to 2 waves of Dutch panel data gathered among 832 retirees. Retirement rituals were measured in 2 ways: via the perceived effort put into the ritual, and via details regarding the presentation of a retirement gift. SWL was assessed through 3 questions of the typical scale. The findings provide evidence that functioning and social connectedness at work positively, and involuntary retirement negatively influence the extensiveness of retirement rituals. These outcomes imply that it is embeddedness at work rather than hierarchal position that shapes retirement rituals. The most important finding is that the experienced retirement ritual is positively associated to postretirement SWL, and mostly so for those who perceive themselves a highly competent in their work. No such interaction was found for retirement anxiety. Although the observed connection between retirement rituals and SWL is not large, this finding is important for employers, employees, and policy makers when considering farewell ceremonies and the rules and customs that surround them, and warrants further research into this relationship.
\end{abstract}

In years to come, many Western countries will experience a demographic shift toward more "gray," or aged, populations. The number of people who consequentially depend on some form of pension benefit will increase substantially, both in an absolute and proportional sense. Given this background, it is ever more valuable to comprehend how work and retirement influence the successful aging of people. Research on the consequences of retirement for well-being has focused on both the preretirement situation, for example, work stress (van den Bogaard, Henkens, \& Kalmijn, 2016; Westerlund et al., 2009), as well as on postretirement aspects, for example, volunteering (Greenfield \& Marks, 2004). What has remained underexposed however, is the ceremony that marks the moment of the transition itself, the retirement ritual. This may be defined as the pivotal moment in which a person relinquishes his or her position in the active labor force, and transitions to the role of retiree in the presence of others. It generally provides the opportunity for others to pay tribute to the retiree's career and person, to jointly look ahead toward retirement, and it serves as a symbolic rite of passage which concludes one stage of life and initiates another. Such a ritual is inherently interesting, as it is the focal social gathering in which the life-long work role may be abandoned. As such, it is a rite that marks a major transition in later life which is shaped within a societal and organizational context. Rituals matter further because they generally function to help people cope with the change they are undergoing. For retirement ceremonies, there is virtually no scientific research on the content or shape of this ritual, and even less investigating whether such a rite of passage has any lasting effect on the wellbeing of the retiree. This study is the first to quantitatively explore the retirement ritual, what factors determine its extensiveness, and how this ritual is related to postretirement satisfaction with life (SWL).

The relevance of retirement rituals has been acknowledged by various scholars in the field of social gerontology (Atchley, 1976; Crawford, 1973; Maddox, 1968; Manheimer, 1994), but their suggestions for research have been pursued only minimally. Notable exceptions are Savishinsky (1995) and Weiss (2005), who conducted multiple personal interviews with a select group of retirees. Although these studies do not structurally examine the factors that determine the size and shape of the ritual or its outcomes, what does emerge from these interviews is that, irrespective of the specifics, heartfelt attention for the career, departure, future, and personal traits of the retiree is pivotal. If a retiree felt that genuine thought and consideration was poured into the retirement ceremony, this seemed to help him or her to make the transition smoothly. On the other hand, retirees who believed that their farewell was superficial and routine report more difficulty in perceiving their career and life afterwards in a positive way.

In-depth personal interviews as mentioned above are interesting and can provide unique insight into a person's life and feelings, but it 
is problematic to draw conclusions beyond the level of the individual. Although the use of quantitative data with comparable and uniform measurements has been suggested to investigate the matter (Jacobson, 1996), such studies seem nonexistent. A first contribution of this study, then, is the use of quantitative data to analyze retirement rituals, and what factors influence their extent. Two measures regarding the ritual are used. First, a subjective measure for the experienced effort that was put into the ceremony according to the retiree, and second, a more objective measure for the receipt of a gift, and from whom it originated (employer, colleagues, or both).

A second contribution of this study is that it examines to what extent the ritual is actually advantageous for people, or more specifically, to what extent retirement rituals influence SWL. Previous research, including retirement studies, has established SWL as a recognized outcome measure for subjective well-being (Diener, Emmons, Larsen, \& Griffin, 1985; Hershey \& Henkens, 2014; Pinquart \& Schindler, 2007), although no study looks into the possible consequences of retirement rituals for SWL. Overall, SWL is relatively high in the Netherlands (Inglehart, 2002; Kapteyn, Smith, \& van Soest, 2010; Veenhoven, 1993), although the comparability of this measure on an international level is debatable (Oishi, 2010). It is a variable that shows remarkable stability over time within individuals, but there is also evidence that major life changes, such as retirement, have the potential to affect satisfaction with life (Diener, 2000; Diener et al., 1985; Dingemans \& Henkens, 2014).

It is further investigated in this study to what extent the influence of the ritual differs across people: the potential benefits of the ceremony may be more relevant for some than for others. Two aspects are studied: the extent to which people perceive themselves as professionally competent, and the anxiety they experience regarding their future retired life.

A notable strength of this study is the use of panel survey data, gathered among 832 Dutch men and women who were interviewed in 2001, when they were all in paid employment, and again in 2006/2007, when they had retired. A challenge in trying to establish possible effects of retirement rituals on SWL is that of unmeasured heterogeneity. Retirees may differ on a characteristic that is related to both the retirement ritual as well as SWL, but not available in the data, which may lead to spurious results. However, the panel design of the data allow us to partly tackle this problem via the inclusion of many preretirement variates, most important of which is the preretirement SWL. The inclusion of this lagged dependent reduces the problem of unmeasured variable bias significantly because this variable is likely to pick up, and thus control for, such unknown characteristics.

The Dutch situation with regard to retirement does not differ substantially from other Western European countries (Commission of the European Union, 2000; Euwals, de Mooij, \& van Vuuren, 2009). Similar to other countries, policies regarding retirement and pensions have been changing or under debate in recent times. While the average age at which people move out of the workforce has been rising, the retirement culture was and remains one of early exit from the labor force (i.e., before age 65 ). The average age at which a person retired in the period between 2001 and 2007 was around 60 years (Siermann \& Dirven, 2005), with less than $10 \%$ remaining in the labor force at age 65. Regarding the retirement ritual it could be argued that, compared to other rites of passage, the lack of tradition is most notable (Maddox, 1968; Manheimer, 1994). Notwithstanding, there is usually some form of social gathering in which the employer, colleagues, and/or family members are involved on a certain level. The retiree is made the center of attention, and is often publicly addressed by co-workers, supervisors, and/or family. A gift may be presented, and there is room for other social exchange in which aspects of the career and the future may be discussed.

\section{THEORETICAL BACKGROUND AND HYPOTHESES}

\section{Determinants of Perceived Retirement Rituals}

As a lead-up to the investigation of the consequences of rituals, first the factors that may shape such rituals are considered briefly. A retirement ritual can be seen as rewarding for the retiree, but also costs time and effort for the organizers and those who are present. From that perspective, it is shaped by the perceived merits and deservingness of the retiree, the willingness to organize and participate in such a ceremony, and the possibilities and constraints that surround such rituals. The specific factors that are taken into account in this study, as well as the reasons for why they may influence the perceived extent of the ritual, are summarized in Table 1.

\section{Why Retirement Rituals May Influence SWL}

Anthropologists have suggested that major life transitions often include periods of considerable "liminality" (Turner, 1987; van Gennep, 1960). Liminality is considered a disorienting state, in which the person undergoing it does not fully hold the preritual status, nor the postritual status. This may lead to uncertainty about social position and hierarchy, questions about identity and behavioral expectations, and prospects about the future may change or become unsure. Rites of passage partly function to deal with liminality: they mark the beginning of a new social status or role as well as the ending of an old one, they may provide the person in concern with information and inspiration regarding their new role, and they function as a gathering where the social network can be informed of the role-change and give support. Overall then, such rituals may help to preserve or improve a person's general SWL (Turner, 1969; van Gennep, 1960).

Applied to retirement, liminality also seems to be at play. The final period at work is often one in which the future retiree is no longer handed any long-term tasks or major responsibilities (Atchley, 1976; Savishinsky, 2000; Weiss, 2005), and often a disengagement from work is already taking place (Damman, Henkens, \& Kalmijn, 2013). The future retiree may also be unsure of his or her identity as the lifelong work role is relinquished. Finally, there may be considerable uncertainty about the future. A retirement ceremony or gift, however, may provide closure at work and offer inspiration and reassurance for the future, all in the presence of the social network. For these reasons, the expectation is that the experience of more extensive retirement rituals will be associated with higher postretirement SWL.

More specifically, rites of passage have been theoretically divided into three types, namely separation rites, which mark the exit from a previous status; transitional rites, performed during the actual transition; and incorporation rites, to mark the entry into the new status (van Gennep, 1960). The retirement ceremony seems a transitional rite, as it often takes place on or near the boundary between work and retirement, but it usually has features that make it overlap with the separation and incorporation categories. It may reflect on the old, 
Table 1. Factors Expected to Influence Retirement Rituals

\begin{tabular}{|c|c|c|}
\hline Variable & Influence & Mechanism \\
\hline Functioning at work & Positive & $\begin{array}{l}\text { An employee functioning below par is likely to be considered less deserving of an extensive } \\
\text { ceremony, primarily by the employer }\end{array}$ \\
\hline Tenure & Positive & $\begin{array}{l}\text { Seniority may instill feelings of deservingness among both employer and co-workers; } \\
\text { organizational rules and culture may lead to more attention for the departure of people who } \\
\text { were connected to a company for a long time }\end{array}$ \\
\hline $\begin{array}{l}\text { Position } \\
\text { Managerial } \\
\text { Socioeconomic status }\end{array}$ & Positive & $\begin{array}{l}\text { Higher positions may be associated with greater perceived merit and therefore deservingness; } \\
\text { organizational rules and culture may lead to more attention for departure from higher } \\
\text { positions }\end{array}$ \\
\hline $\begin{array}{l}\text { Connectedness at work } \\
\text { Co-workers as friends } \\
\text { Quality of collegial contacts }\end{array}$ & Positive & $\begin{array}{l}\text { Farewell ceremonies and the presentation of a gift are often (co-)organized by colleagues, } \\
\text { so high quantity and quality of relationships with co-workers will lead to more possible } \\
\text { organizers, as well as willingness to organize a ceremony or present a gift }\end{array}$ \\
\hline $\begin{array}{l}\text { Involuntary retirement } \\
\text { Employer } \\
\text { Health } \\
\text { Other }\end{array}$ & Negative & $\begin{array}{l}\text { Retirement for health reasons may cause a lack of proper time and place for a ceremony or a } \\
\text { gift, as retirement may be relatively sudden; with employer-induced retirement the employer } \\
\text { may be unwilling or unable to provide the necessary conditions such as funding, time, and } \\
\text { space; retirees may be unwilling to participate in a ceremony or accept a gift after being made } \\
\text { redundant }\end{array}$ \\
\hline
\end{tabular}

working, status, and it may pay attention to the achievement of the new, retired, status. From this perspective, it can be expected that people differ in the impact a retirement ritual has on them, because they differ in the degree to which such a ceremony suits their need for recognition of past achievements and for looking ahead. As regards looking back at the career, some people may feel more than others that they have played a valuable role in their work field, that they have achieved important things, and that they are good at what they do. In such a case, a retirement ceremony or gift may have added value. Fellow workers or a supervisor may present a gift, address the retiree and confirm his or her contributions and recognize his or her efforts. This may instill appreciation and validation within the retiree, and confirm his or her deservingness of a ritual, which is positive for SWL. For retirees who feel less positive about their career and capabilities, retirement rituals may be less influential for SWL, as there are less feelings of deservingness. The expectation is therefore that the positive association between retirement rituals and postretirement $S W L$ is stronger for retirees with high perceived competence.

Attention for the new social status of retiree might seem less obvious at the departure ceremony, but in many cases this issue is addressed (Savishinsky, 1995; Weiss, 2005). This may be done by bestowing a gift related to future leisure activities (e.g., golf clubs or a travel bag), and by exchanging and discussing plans and ideas for future endeavors. Overall, this attention for the new role of the retiree is important, because it can provide suggestions or guidelines for future activities and clarify expectations about retired life. It can generate understanding and tolerance with the social network visà-vis the changes that the retiree faces, fostering support. But perhaps most importantly, it may take away fear of the unknown, or at least give courage to deal with this fear (Pickering, 1974). If a person experiences substantial anxiety about retirement and the life it entails, then the experience of an attentive retirement ceremony or gift is expected to be extra valuable for dealing with this anxiety. The expectation is that the positive association between retirement rituals and postretirement SWL is stronger for retirees with more anxiety about retirement.

\section{DATA AND METHODS}

The data for this study stem from the Work and Retirement Panel, an ongoing investigation by the Netherlands Interdisciplinary Demographic Institute (NIDI). The collection of data took place among (a) all employees aged 50-64 of more than 80 businesses attached to three large Dutch multinational corporations, active in manufacturing, retail, and information technology, as well as among (b) a random sample of equally aged civil servants of the Dutch central government. For the first wave $\left(t_{1}, 2001\right)$, a total of 3,899 people were mailed a questionnaire, of which 2,403 responded (response rate $62 \%)$. A follow-up was conducted in 2006/2007 ( $\left.t_{2}\right)$, where some attrition occurred because of company takeovers $(N=122)$, untraceable participants $(N=11)$, and mortality $(N=41)$. A total of 1,678 people responded of the 2,239 who were contacted (response rate $75 \%$ ). To select retired respondents, only those who moved from being in paid employment at $t_{1}$ to receiving a pension or early retirement benefit at $t_{2}$ were chosen for the final sample. Following Pinquart and Schindler (2007), a small group of respondents still receiving wages after retirement (thus also receiving retirement benefits) were excluded since the data do not offer the possibility to unequivocally establish the work status for these people. Further, this group is too small to allow for useful separate analyses $(N=36)$. To what extent this may bias outcomes is discussed in the conclusions. A total of 891 respondents experienced retirement and were able to answer questions regarding their retirement ceremony. Unfortunately, 59 cases (6\%) were removed because of missing information on various variables. The final sample consists of 832 respondents, all of whom were working at $t_{1}$ and moved to being fully retired at $t_{2}$.

\section{Measurements}

SWL is measured at both waves through three Likert taken from the widely used and recognized scale by Diener and colleagues (1985), see Table 2 for further specifics. It is a measure for subjective well-being, and was purposely developed to assess a persons' satisfaction with life as a whole, allowing people to consciously evaluate different domains of their life and assign weight to them using their personal criteria 
Table 2. Descriptive Statistics, Wording and Coding of (Unstandardized) Variables

\begin{tabular}{|c|c|c|c|}
\hline Variable & Mean & $S D$ & Description \\
\hline SWL $t_{1}$ & 2.65 & 0.62 & $\begin{array}{l}\text { Three-item mean scale, based on Diener and colleagues (1985): The conditions } \\
\text { of my life are excellent; So far I have gotten the important things I want in my life; } \\
\text { In most ways my life is close to ideal. Response categories: } 0=\text { strongly disagree, } \\
4 \text { = strongly agree. Cronbach's alpha: } .71\end{array}$ \\
\hline SWL $t_{2}$ & 2.72 & 0.63 & See SWL $t_{1}$. Cronbach's alpha: .75 \\
\hline Perceived retirement ritual & 2.40 & 1.25 & $\begin{array}{l}\text { Agreement with statement there was a lot of effort put into my farewell at work. } \\
\text { Response categories: } 0=\text { strongly disagree, } 4=\text { strongly agree. Standardized, } \\
\text { range: }-1.94 \text { to } 1.26 .\end{array}$ \\
\hline Retirement gift: no & 0.11 & 0.31 & $\begin{array}{l}\text { Dummy indicating whether respondent received a farewell present, based on } \\
\text { item did you receive a gift or memorial for your departure from work? Response } \\
\text { categories: no; yes, from colleagues; yes, from the company/organization; yes, } \\
\text { from colleagues and the company/organization. }\end{array}$ \\
\hline Retirement gift: colleagues & 0.31 & 0.46 & See Retirement gift: no \\
\hline Retirement gift: employer & 0.05 & 0.21 & See Retirement gift: no \\
\hline Retirement gift: both & 0.54 & 0.50 & See Retirement gift: no \\
\hline Retirement anxiety $t_{1}$ & 1.10 & 0.60 & $\begin{array}{l}\text { Five-item mean scale, based on items asking people to indicate how much they } \\
\text { expect to miss the following after retirement: money; social contacts; prestige/ } \\
\text { status; self-worth; a regular life. Response categories: not at all (0); a little; fairly; } \\
\text { much; very much (4). Standardized, range }-1.87 \text { to } 4.60 \text {. Cronbach's alpha: .67 }\end{array}$ \\
\hline Perceived competence $t_{1}$ & 4.31 & 0.87 & $\begin{array}{l}\text { Five-item mean scale: On my work I am able to solve my problems well; I find } \\
\text { I do my work well; When I finish something on my work it brightens me up; } \\
\text { In this job I have reached a lot of valuable things; and On my job I glow with } \\
\text { self-confidence. Response categories: never (0); sporadically; now and then; } \\
\text { regularly; often; very often; always (6). Standardized, range: }-4.10 \text { to } 1.89 \text {. } \\
\text { Cronbach's alpha: } 67\end{array}$ \\
\hline Perceived functioning $t_{1}$ & 2.69 & 0.63 & $\begin{array}{l}\text { Based on item are you presently functioning well at work? Response categories: not } \\
\text { well at all ( } 0 \text { ); not very well; reasonably well; yes, well (3). Standardized for } \\
\text { analyses (range }-4.8 \text { to } 0.44 \text { ) }\end{array}$ \\
\hline Years in function $t_{1}: 0-5$ & 0.28 & 0.45 & Series of dummies, based on item How long have you fulfilled your current function? \\
\hline Years in function $t_{1}: 6-10$ & 0.22 & 0.41 & See Years in function: $0-5$ \\
\hline Years in function $t_{1}: 11-15$ & 0.17 & 0.37 & See Years in function: $0-5$ \\
\hline Years in function $t_{1}: 16-20$ & 0.10 & 0.30 & See Years in function: $0-5$ \\
\hline Years in function $t_{1}:>20$ & 0.24 & 0.43 & See Years in function: $0-5$ \\
\hline Managerial position $t_{1}$ & 0.26 & 0.44 & Based on item do you have a managerial position? $(1$ = yes) \\
\hline ISEI $t_{1}$ & 54.23 & 13.71 & $\begin{array}{l}\text { ISEI for status of the job, available in dataset. See Ganzeboom, de Graaf, and } \\
\text { Treiman (1992) }\end{array}$ \\
\hline Co-workers as friends $t_{1}$ & 1.12 & 0.84 & $\begin{array}{l}\text { Based on agreement with statement } I \text { know most of my friends through my work. } \\
\text { Response categories: } 0=\text { strongly disagree, } 4=\text { strongly agree. Standardized, } \\
\text { range }-1.33 \text { to } 3.31\end{array}$ \\
\hline Quality of collegial contacts $t_{1}$ & 3.16 & 0.68 & $\begin{array}{l}\text { Based on agreement with statement the relationship with my colleagues is excellent. } \\
\text { Response categories: } 0=\text { strongly disagree, } 4=\text { strongly agree. Standardized, } \\
\text { range }-4.65 \text { to } 1.26\end{array}$ \\
\hline Contact former colleagues $t_{2}$ & 1.36 & 0.69 & $\begin{array}{l}\text { Item: How frequently are you in contact with your former colleagues? Response } \\
\text { categories: never (0); seldom; regularly; often (4) }\end{array}$ \\
\hline Involuntary retirement: health & 0.08 & 0.27 & $\begin{array}{l}\text { Dummy indicating if retirement was caused by personal health issues. Based on } \\
\text { items was the decision to stop working completely voluntary?, and, if no, what was } \\
\text { it that made your decision (partly) involuntary? Response categories: own health; } \\
\text { health of spouse; health of other person; pressure from employer; pressure } \\
\text { from colleagues; partner; reaching obligatory pension age; other. }\end{array}$ \\
\hline $\begin{array}{l}\text { Involuntary retirement: } \\
\text { employer }\end{array}$ & 0.15 & 0.36 & $\begin{array}{l}\text { Dummy indicating if retirement was caused by pressure from employer. See } \\
\text { Involuntary retirement: health. }\end{array}$ \\
\hline
\end{tabular}


Table 2. Continued

\begin{tabular}{|c|c|c|c|}
\hline Variable & Mean & $S D$ & Description \\
\hline Involuntary retirement: other & 0.08 & 0.27 & $\begin{array}{l}\text { Dummy indicating if retirement was the result of things other than personal } \\
\text { health or pressure from employer. See Involuntary retirement: health. }\end{array}$ \\
\hline \multicolumn{4}{|l|}{ Controls } \\
\hline Retirement age & 58.73 & 2.64 & Age at moment of retirement. Standardized, range -2.64 to 2.48 \\
\hline Central government & 0.38 & 0.48 & $\begin{array}{l}\text { Series of dummies indicating where respondent was employed: central } \\
\text { government or one of three multinational corporations }\end{array}$ \\
\hline Company 1 & 0.24 & 0.43 & See Central government \\
\hline Company 2 & 0.22 & 0.41 & See Central government \\
\hline Company 3 & 0.17 & 0.38 & See Central government \\
\hline Low education & 0.39 & 0.49 & $\begin{array}{l}\text { Indicator for highest completed level of education. } 1 \text { = elementary school, lower } \\
\text { vocational. }\end{array}$ \\
\hline Middle education & 0.29 & 0.45 & $\begin{array}{l}\text { See Low education. } 1 \text { = (preparatory) middle-level vocational education; higher } \\
\text { secondary education. }\end{array}$ \\
\hline High education & 0.32 & 0.47 & See Low education. 1 = higher vocational; university or higher. \\
\hline Female & 0.23 & 0.42 & $0=$ male $; 1=$ female \\
\hline No partner $t_{2}$ & 0.13 & 0.33 & Partner status of respondent. $0=$ partner; $1=$ no partner \\
\hline Child(ren) in household $t_{1}$ & 0.25 & 0.44 & Indicator for children living in the household. 1 = yes. \\
\hline Income $t_{2}$ & 2,749 & 1,111 & Net household income. Standardized, range -2.35 to 3.75 \\
\hline Age $t_{1}$ & 55.43 & 2.77 & Age at $t_{1}$. Standardized, range -1.47 to 3.43 \\
\hline Self-rated health $t_{1}$ & 3.00 & 0.88 & $\begin{array}{l}\text { Based on item how is your health, in general? Response categories: very bad ( } 0 \text { ) to } \\
\text { very good (4). Standardized, range }-3.75 \text { to } 1.12\end{array}$ \\
\hline
\end{tabular}

Note. $N$ of observations is 832 for all variables. ISEI = International Socio-economic Index; $S D=$ standard deviation; SWL = satisfaction with life.

(Pavot \& Diener, 1993). A possible difficulty of this measure may be its subjective and retrospective nature. It not only surveys the contemporary situation, but also requires a person to reflect on his or her life as a whole. Because of this, it may be linked in a relatively strong way to retirement rituals, as these are aimed at providing contentment and closure for major parts of a persons' life. This will be considered further in the discussion.

To assess features of the retirement ceremony, two variables are used. The first variable measured the experienced extensiveness of the ritual by asking the respondent to indicate his or her agreement on a 5-point Likert scale with the following statement: "There was a lot of effort put into my farewell at work." The formulation of this item means it focuses on the involvement of colleagues and supervisors, rather than other social spheres such as friends and family. While the subjective and restricted nature of this item limits the extent to which it covers the concept of retirement rituals as defined earlier, it provides valuable information on respondents' personal evaluation of the attention for his or her career, individuality, and future, by inquiring how they assess the labor and consideration that was poured into the ritual. A second, more objective measure assessed whether the respondent was presented with a gift for his or her departure from work, and if yes, by whom: colleagues, the employer, or a combination of the two. This also taps into the involvement and attention from co-workers and supervisors, who play an important part in the retirement ritual, since these people have spent much time with the retiree in the role that is being relinquished. Descriptive outcomes of these questions will be considered in the results section.

Retirement anxiety is measured at $t_{1}$ by a mean scale made up of five items, all asking the respondent to indicate on a 5-point scale how much they expect to miss the following in retirement: money; social contacts; prestige/status; self-worth; a regular life (Cronbach's alpha $.67)$. These measures have been used in prior research, and shown to be an important predictor of retirement adjustment and satisfaction (van Solinge \& Henkens, 2008). Self-perceived professional competence is measured at $t_{1}$ by a recognized scale (Cronbach's alpha .67) used in prior research (Henkens \& Leenders, 2010; Schaufeli \& van Dierendonck, 2000), consisting of five items, such as: "I find I do my work well" and "In this job I have reached a lot of valuable things." Respondents were asked to indicate where they stood on a 7-point answer scale ranging from "never" (0) to "always" (6). Descriptive statistics, wording of questions and coding schemes for these and all other variables are presented in Table 2.

\section{Analytical Strategy}

First, it is examined in a bivariate way to what extent the experienced ritual and the retirement gift are related. Second, the factors expected to influence retirement rituals will be investigated through regression analyses with both the experienced ritual and the gift variable as dependent variables. Finally, possible effects of the ritual on SWL will be studied by regressing SWL $t_{2}$ on a set of predictors, including the ritual variables and $S W L t$. This latter variable controls for the baseline level of SWL, and as such, provides a more accurate test for the effects of the ritual variables. The method used is thus a lagged dependent model (Allison, 1994; Finkel, 1995).

Besides the lagged dependent, other important variables are included that may confound the relationship between the retirement ritual and SWL. Involuntary retirement, for example, is known to lead to lower levels of SWL compared to voluntary retirement (Hershey \& Henkens, 2014). At the same time, it is likely that for a person who is forced out of a job, retirement rituals will be nonexistent or less 
heartfelt. In such a case, the relation between the ritual and SWL is - at least partly-spurious. Other possible confounders that are included are the respondent's position and (perceived) functioning at work at $t_{1}$, and properties of the relationship with colleagues before and after retirement. Further control variables include tenure, age, age at retirement, educational level, gender, partner status at $t_{2}$, presence of children in the household at $t_{1}$, income at $t_{2}$, and self-rated health at $t_{1}$. While these constructs may not be expected to directly influence the relationship between retirement rituals and SWL from a theoretical perspective, they are added to ensure a more precise test of the ritual variables. See Table 2 for more information on all variables.

For additional insight into the associations between the variables in this study, Table 3 includes the correlations between all variables in this study. It reveals most of the relationships that are further explored in the remainder of this article. For example, the importance of the retirement gift for the perceived ritual, the importance of colleagues for the ritual, and how the ritual variables are related to SWL. In general it seems to show no surprising correlations, except perhaps for the correlations between the perceived retirement ritual and the gift variables. It must be noted however, that the latter are dummy coded, with zero meaning all else. This leads to biased correlation estimates.
More insight into the relationship between the perceived ritual and retirement gifts can be obtained from Table 4 .

\section{RESULTS}

\section{Descriptive Information on the Retirement Ritual}

Overall, almost $60 \%$ of the respondents (strongly) agrees that much effort was put into the ritual. However, this also leaves a large minority (44\%) that does not feel this way, and about a quarter of the respondents (strongly) disagrees with the statement. Table 4 provides information on the amount of respondents that received a gift, and from whom it came. Only a minority reports receiving nothing (11\%), while a little under one-third was presented with a gift from colleagues only. A majority (54\%) collected a gift from both direct colleagues and the employer. Five percent of the respondents indicated they received a gift from the employer only. The table also shows that there is a connection between receiving a gift or memorial, from whom it came, and how people experienced their retirement ritual. The people collecting nothing at all score the lowest on the retirement ritual variable. Those who did receive a token of appreciation scored significantly higher on the variable (2.63, not in table), but it also matters what the source of the gift was: when colleagues were involved people generally experienced

Table 3. Pairwise Correlations Between Variables of Interest in the Study

\begin{tabular}{|c|c|c|c|c|c|c|c|c|c|c|c|c|c|}
\hline & $(1)$ & $(2)$ & (3) & (4) & (5) & (6) & $(7)$ & $(8)$ & (9) & $(10)$ & $(11)$ & $(12)$ & $(13)$ \\
\hline \multicolumn{14}{|l|}{ Perceived retirement ritual (1) } \\
\hline Retirement gift: colleagues (2) & $-.09^{*}$ & & & & & & & & & & & & \\
\hline Retirement gift: employer (3) & $-.12^{*}$ & $-.15^{*}$ & & & & & & & & & & & \\
\hline Retirement gift: both (4) & $.47^{*}$ & $-.72^{*}$ & $-.24^{*}$ & & & & & & & & & & \\
\hline Retirement gift: none (5) & $-.55^{*}$ & $-.23^{*}$ & $-.08^{*}$ & $-.38^{*}$ & & & & & & & & & \\
\hline SWL $t_{1}(6)$ & $.13^{*}$ & $-.09^{*}$ & .01 & $.14^{*}$ & $-.09^{*}$ & & & & & & & & \\
\hline SWL $t_{2}(7)$ & $.21^{*}$ & .01 & -.05 & $.09^{*}$ & $-.13^{*}$ & $.48^{*}$ & & & & & & & \\
\hline Perceived funtioning $t_{1}(8)$ & $.19^{*}$ & -.00 & -.04 & $.10^{*}$ & $-.13^{*}$ & $.14^{*}$ & $.11^{*}$ & & & & & & \\
\hline Years in function (interval) $t_{1}(9)$ & -.01 & .04 & .01 & -.06 & .03 & .04 & .02 & .03 & & & & & \\
\hline Managerial position $t_{1}(10)$ & .04 & -.02 & -.04 & .03 & .00 & $.11^{*}$ & $.12^{*}$ & $.10^{*}$ & $-.13^{*}$ & & & & \\
\hline ISEI $t_{1}(11)$ & -.06 & .01 & -.05 & .01 & .00 & .06 & $.09^{*}$ & -.05 & $-.19^{*}$ & $.21^{*}$ & & & \\
\hline Colleagues: friends $t_{1}(12)$ & $.10^{*}$ & .04 & -.02 & .01 & $-.07^{*}$ & $-.11^{*}$ & -.06 & .00 & -.01 & $.09^{*}$ & .03 & & \\
\hline Quality of collegial contacts $t_{1}(13)$ & $.21^{*}$ & -.06 & -.03 & $.13^{*}$ & $-.10^{*}$ & $.20^{*}$ & $.15^{*}$ & $.24^{*}$ & $.09^{*}$ & -.00 & $-.07^{*}$ & .07 & \\
\hline Contact former colleagues (14) & $.32^{*}$ & -.05 & -.07 & $.17^{*}$ & $-.15^{*}$ & .05 & .03 & $.09^{*}$ & .02 & .00 & $-.11^{*}$ & $.15^{*}$ & $.15^{*}$ \\
\hline Invol. retirement: health (15) & $-.11^{*}$ & .02 & .04 & $-.11^{*}$ & $.11^{*}$ & -.06 & $-.16^{*}$ & $-.24^{*}$ & -.03 & $-.07^{*}$ & .02 & -.02 & -.05 \\
\hline Invol. retirement: employer (16) & $-.24^{*}$ & $-.07^{*}$ & $.12^{*}$ & $-.11^{*}$ & $.20^{*}$ & -.05 & $-.12^{*}$ & $-.07^{*}$ & .01 & .01 & .02 & -.01 & -.02 \\
\hline Invol. retirement: other (17) & .01 & -.01 & .00 & -.01 & .02 & .00 & -.06 & .02 & -.02 & $.09^{*}$ & -.05 & -.03 & -.02 \\
\hline Years retired (18) & -.01 & .00 & .02 & -.01 & .00 & $.08^{*}$ & $.07^{*}$ & $-.09^{*}$ & .06 & .01 & .02 & .04 & -.02 \\
\hline Perceived competence (19) & $.15^{*}$ & $-.11^{*}$ & -.03 & $.14^{*}$ & -.04 & $.29^{*}$ & $.17^{*}$ & $.33^{*}$ & $.08^{*}$ & $.11^{*}$ & .06 & .04 & $.28^{*}$ \\
\hline \multirow[t]{2}{*}{ Retirement anxiety (20) } & -.01 & -.00 & .02 & -.02 & .03 & $-.12^{*}$ & $-.17^{*}$ & -.00 & .04 & -.07 & -.05 & $.21^{*}$ & .04 \\
\hline & $(14)$ & $(15)$ & $(16)$ & $(17)$ & $(18)$ & $(19)$ & & & & & & & \\
\hline \multicolumn{14}{|l|}{ Contact former colleagues (14) } \\
\hline Invol. retirement: health (15) & -.04 & & & & & & & & & & & & \\
\hline Invol. retirement: employer (16) & $-.12^{*}$ & $-.12^{*}$ & & & & & & & & & & & \\
\hline Invol. retirement: other (17) & -.00 & $-.08^{*}$ & $-.12^{*}$ & & & & & & & & & & \\
\hline Years retired (18) & $-.13^{*}$ & .02 & .00 & $-.08^{*}$ & & & & & & & & & \\
\hline Perceived competence (19) & .05 & -.06 & -.00 & -.02 & -.00 & & & & & & & & \\
\hline Retirement anxiety (20) & $.08^{*}$ & .04 & $.07^{*}$ & .06 & -.03 & .01 & & & & & & & \\
\hline
\end{tabular}

Note. $N$ of observations is 832 for all variables. ISEI = International Socio-economic Index; SWL = satisfaction with life. ${ }^{*} p<.05$. 
more extensive retirement rituals. If both colleagues and the employer were involved the ritual was rated highest (2.94).

When the seemingly ordinal nature of the gift variables is used to create a single ordinal variable, the correlation between this variable and the perceived retirement ritual is .62 $(p<.01)$. This is in line with findings from Savishinsky (2000) and Weiss (2005), who report that a personal touch tends to add to the ritual experience, and that this

Table 4. Distribution of Farewell Gift or Memorial for Retirement and Mean Score on Retirement Ritual Variable ${ }^{a, b}$

$\%$ of Total $(N) \quad$ Mean Score on Unstandardized Retirement Ritual Variable $(S D)$

\begin{tabular}{lcc} 
No gift & $11(88)$ & $0.41(0.67)$ \\
Gift from employer & $5(38)$ & $1.71(1.11)$ \\
Gift from colleagues & $31(254)$ & $2.22(1.09)$ \\
$\begin{array}{l}\text { Gift from colleagues } \\
\quad \text { and employer }\end{array}$ & $54(452)$ & $2.94(0.96)$ \\
Total & $100(832)$ & $2.40(1.25)$ \\
\hline
\end{tabular}

Note. $S D=$ standard deviation.

${ }^{2}$ Agreement with statement: there was a lot of effort put into my farewell at work (range: $0-4$ ).

${ }^{\mathrm{b}}$ All differences between groups are significant $(p<.01)$. personal touch was often provided by direct colleagues, rather than management or a human resource department.

\section{Determinants of the Retirement Ritual}

What determines the extensiveness of the experienced retirement ritual? Table 5 presents parallel analyses aimed at answering this question. In Model 1, the dependent variable is the experienced effort put into the retirement ritual. In Model 2, the dependent variable is a construct based on the ordinal structure of the gift variables, which was used in an ordinal logistic regression. The order of the dependent variable is as in Table 4, and the dependent variable thus ranges from 0 (no gift) to 3 (gift from colleagues and employer). The models show only the variables of interest for reasons of brevity and clarity. All results including control variables are available from the author on request.

The better a person felt about his or her functioning, the more extensive the ritual was $(B=.08 ; p<.05)$. No structural association with tenure was found, and neither holding a managerial position or the socioeconomic status of the job appear to make a difference. For the receipt of a gift (Model 2), a significant relation is found for none of these variables. The quality of collegial contacts is found to have a significant association with the ritual: both the experienced effort as well as the gift are positively connected to co-worker connections $(B=.15$; $p<.001$ and $B=.18 ; p<.05$, respectively), although no significant coefficient of having colleagues as friends is found for the receipt retirement gift. As expected, different types of involuntary retirement are

Table 5. Regression Results for Analyses With Perceived Retirement Ritual and Retirement Gift as Dependent Variables (Standard Errors)

\begin{tabular}{lcc}
\hline & Perceived Ritual (OLS Regression) & Receipt of Gift ${ }^{\mathrm{a}}$ Ordinal Logistic Regression) $^{-}$ \\
\hline Perceived functioning $t_{1}$ & $.08^{*}(.03)$ & $.08(.07)$ \\
Years in function $t_{1}: 0-5^{\mathrm{b}}$ & $.10(.10)$ & $.28(.22)$ \\
Years in function $t_{1}: 6-10^{\mathrm{b}}$ & $.12(.11)$ & $.27(.23)$ \\
Years in function $t_{1}: 16-20^{\mathrm{b}}$ & $.17(.13)$ & $.45(.28)$ \\
Years in function $t_{1}:>20^{\mathrm{b}}$ & $.01(.10)$ & $-.18(.22)$ \\
Managerial position $t_{1}$ & $.06(.08)$ & $.02(.18)$ \\
ISEI $t_{1}$ & $-.00(.00)$ & $.00(.01)$ \\
Colleagues: friends $t_{1}$ & $.08^{*}(.03)$ & $.05(.07)$ \\
Quality of collegial contacts $t_{1}$ & $.15^{* * *}(.03)$ & $.18^{*}(.07)$ \\
Involuntary retirement: health & $-.86^{* *}(.27)$ \\
Involuntary retirement: employer & $-.39^{* *}(.13)$ & $-1.01^{* * *}(.20)$ \\
Involuntary retirement: other & $-.62^{* * *}(.09)$ & $-.49^{+}(.27)$ \\
Constant & $-.22^{+}(.13)$ & \\
Cut $1^{\mathrm{d}}$ & $-.31(.24)$ & $-1.33^{*}(.54)$ \\
Cut 2 & & $-.88^{+}(.53)$ \\
Cut 3 & & $.81(.53)$ \\
(Pseudo) $R^{2}$ & & .052 \\
-2 log likelihood & .196 & -846 \\
Observations & & 832 \\
\hline
\end{tabular}

Note. Controls not in table: company; retirement age; age; education; children in household $t_{1}$; gender; partner status $t_{2}$; income $t_{2}$; self-rated health $t_{1}$; SWL $t_{1}$. ISEI = International Socio-economic Index

${ }^{a} 0$ = no gift; 1 = gift from employer; 2 = gift from colleagues; 3 = gift from both.

beference: years in function: $10-15$.

'Reference: voluntary retirement.

${ }^{\mathrm{d}}$ Cut off points are scores on the latent variable that differentiate between each category of the ordinal dependent variable, or thresholds that need to be crossed to get to the next (higher) category from the category below.

${ }^{+} p<.10,{ }^{*} p<.05,{ }^{* *} p<.01,{ }^{* * *} p<.001$. 
associated with less extensive retirement rituals compared to voluntary retirement. This is true for both the experienced ritual, as well as the receipt of a gift, and is found for all included types of involuntary retirement, although the category "other" achieves only borderline statistical significance. Retirement enforced by the employer is most negatively related to both variables that tap into the ritual. Summarizing, this table shows that the aspects investigated here-job circumstances, the workplace as a social setting, and (in)voluntariness of the transition, all matter to some extent for the retirement ritual.

\section{Retirement Rituals and Satisfaction With Life}

On average, the retirees included in this study experienced a small drop in satisfaction with life, from 2.72 at $t_{1}$ to 2.65 at $t_{2}$ (Table 2). However, additional analyses show that this change mirrors that of the group which remained in employment: from 2.72 to 2.64. Overall, then, retirement is not associated with a change in life satisfaction.

Does the experienced retirement ritual matter for postretirement SWL? Model 1 in Table 6 provides evidence that this is indeed the case: the experience of a more extensive retirement ritual is positively associated with SWL at $t_{2}(B=.10 ; p<.001)$. This model controls for SWL $t_{1}$, as does Model 2, which is aimed at investigating other possible confounders. None of these achieve statistical significance, with the clear exception of the variables on involuntary retirement. As has been shown in earlier research (Hershey \& Henkens, 2014), different types of involuntary retirement are negatively related to SWL. Retiring for health reasons seems most detrimental $(B=-.34 ; p<.001)$, followed by retirement forced by the employer $(B=-.21 ; p<.001)$ and other types of involuntary retirement, such as health problems of a spouse or close relatives $(B=-.19 ; p<.01)$. More interestingly however, additional analyses reveal that it is mostly these variables on involuntary retirement that lead to the drop in the coefficient of the perceived retirement ritual variable, which decreases from .100 in Model 1 to .081 in Model 2, indicating that part of the association between the retirement ritual and SWL is spurious. Still, a coefficient for the retirement ritual remains which is strongly significant $(B=.08 ; p<.001)$. Since the independent variable is standardized, this means that a rise of $1 S D$ of the retirement ritual variable is associated with a change of .08 on SWL $t_{2}$. Looking at the distribution of this dependent variable, this would indicate a small effect in terms of effect size. The association is not explained away by a multitude of variables, however, which indicates its robustness.

Models 3 and 4 follow the same approach as earlier, but with the variables for the retirement gift and its giver replacing the variable for the experienced ritual. As shown in Model 3, gifts from colleagues (whether or not in collaboration with the employer) were significantly related to higher SWL at $t_{2}$ compared to not receiving a gift $(B=.21 ; p$ $<.01$ for a gift from colleagues and $B=.17 ; p<.01$ for a gift from both colleagues and the employer), but these coefficients decrease considerably after the inclusion of possible confounders in Model 4 (to .13 and .08 , respectively). Here again, additional analyses show that this is due to the inclusion of the variables for involuntary retirement. It seems that the relationship between the gift and SWL is largely spurious: involuntary retirement is related to both the bestowal of a gift and SWL. Only the receipt of a gift from colleagues alone, compared to no

Table 6. Results of Conditional Change Regression of SWL at $t_{2}$ on Perceived Retirement Ritual and Other Variables (Standard Errors)

\begin{tabular}{|c|c|c|c|c|}
\hline & Model 1 & Model 2 & Model 3 & Model 4 \\
\hline Perceived retirement ritual & $.10^{* * *}(.02)$ & $.08^{* * *}(.02)$ & & \\
\hline Retirement gift: employer ${ }^{a}$ & & & $.01(.10)$ & $-.01(.10)$ \\
\hline Retirement gift: colleagues ${ }^{\mathrm{a}}$ & & & $.21^{* *}(.07)$ & $.13^{+}(.07)$ \\
\hline Retirement gift: both ${ }^{a}$ & & & $.17^{* *}(.06)$ & $.08(.07)$ \\
\hline Perceived functioning $t_{1}$ & & $-.01(.02)$ & & $-.01(.02)$ \\
\hline Years in function $t_{1}: 0-5^{\mathrm{b}}$ & & $-.04(.06)$ & & $-.03(.06)$ \\
\hline Years in function $t_{1}: 6-10^{\mathrm{b}}$ & & $.04(.06)$ & & $.04(.06)$ \\
\hline Years in function $t_{1}: 16-20^{\mathrm{b}}$ & & $.06(.07)$ & & $.08(.07)$ \\
\hline Years in function $t_{1}:>20^{\mathrm{b}}$ & & $.02(.06)$ & & $.02(.06)$ \\
\hline Managerial position $t_{1}$ & & $.05(.05)$ & & $.06(.05)$ \\
\hline ISEI $t_{1}$ & & $.00(.00)$ & & $.00(.00)$ \\
\hline Colleagues: friends $t_{1}$ & & $-.03(.02)$ & & $-.03(.02)$ \\
\hline Quality of collegial contacts $t_{1}$ & & $.03^{+}(.02)$ & & $.04^{*}(.02)$ \\
\hline Contact former colleagues $t_{2}$ & & $-.03(.03)$ & & $-.01(.03)$ \\
\hline Invol. retirement: health ${ }^{c}$ & & $-.34^{* * *}(.07)$ & & $-.35^{* * *}(.08)$ \\
\hline Invol. retirement: employer ${ }^{c}$ & & $-.21^{* * *}(.05)$ & & $-.23^{* * *}(.05)$ \\
\hline Invol. retirement: other ${ }^{c}$ & & $-.19^{* *}(.07)$ & & $-.20^{* *}(.07)$ \\
\hline $\operatorname{SWL} t_{1}$ & $.39^{* * *}(.03)$ & $.37^{* * *}(.03)$ & $.40^{* * *}(.03)$ & $.37^{* * *}(.03)$ \\
\hline Constant & $1.59^{* * *}(.10)$ & $1.70^{* * *}(.14)$ & $1.40^{* * *}(.11)$ & $1.56^{* * *}(.15)$ \\
\hline$R^{2}$ & .287 & .324 & .274 & .315 \\
\hline Observations & 832 & 832 & 832 & 832 \\
\hline
\end{tabular}

Note. Controls not in table: company; retirement age; age; education; children in household $t_{1}$; gender; partner status $t_{2}$; income $t_{2}$; self-rated health $t_{1}$. ISEI $=$ International Socio-economic Index; SWL = satisfaction with life. Reference categories: ${ }^{\mathrm{a} N o}$ gift; 'Years in job: 10-15; 'Voluntary retirement. ${ }^{+} p<.10,{ }^{*} p<.05,{ }^{* *} p<.01,{ }^{* * *} p<.001$. 
gift at all, is associated with better SWL on a statistically tolerable level $(p=.064)$.

Table 7 presents the results of analyses aimed at investigating interaction effects between the experienced retirement ritual, perceived competence, and retirement anxiety. As is shown in Model 1, a significant interaction between the ritual and perceived competence is found: when a person considered himself or herself as professionally competent, the ritual seems to be more important for SWL $(B=.05 ; p<.01)$. This indicates that people who view themselves as highly competent may come to expect a certain level of attention for their departure, and feel relatively deprived when their farewell is below expectations. Since the variable for perceived competence is standardized, this means that being one standard deviation below or above the average perceived competence corresponds with coefficients for the ritual of .03 and .13 , respectively. These are substantial differences. Retirement anxiety seems to directly affect SWL: more pre-retirement anxiety is related to less post-retirement SWL $(B=-.05 ; p<.05)$. However, the role of the retirement ritual for SWL does not appear to be more salient for people who experienced more retirement anxiety. The coefficient for the interaction is near zero, and insignificant $(B=.01)$.

As a supplement to the previous analyses, Model 3 addresses the durability of the suggested retirement ritual effect. This is done by interacting the perceived ritual variable with a variable that indicates the time in years since retirement, which is centered around the average of 2.8 years. The interaction coefficient is negative and borderline significant $(B=-.02 ; p=.056)$ which indicates that the association between the ritual and higher SWL diminishes over time. Additional analyses with a number of dummy variables for the number of years passed since retirement reveal comparable results, including a linear decrease in the coefficient over time. Model 4, finally, includes all three interactions and corroborates the finding from previous models.

The significant interactions are graphically depicted in Figure 1. Note that in the models specified in Table 7 , a negative effect of the perceived ritual on SWL is predicted for the lowest levels of perceived competence. This may indicate that people with low levels of perceived competence are discomforted by a more extensive retirement ritual. However, on the scale for perceived competence, only about $6 \%$ of respondents score below 3 , the point at which the effect of the perceived ritual turns negative. Problems of statistical power may thus make firm statements about this group difficult.

As a robustness check, all analyses with SWL $t_{2}$ as the dependent variable were also performed with a fixed effects specification, namely modeling the change in SWL rather than SWL $t_{2}$ while controlling for SWL $t_{1}$. This yielded comparable results, except that the interaction with perceived competence did not achieve statistical significance. These analyses are available from the author on request.

\section{CONCLUSION AND DISCUSSION}

By employing a strong analytic design of panel data, this study has provided empirical insight into the factors that shape retirement rituals, and has offered evidence that the experience of an extensive retirement ritual is positively related to postretirement satisfaction with life.

Table 7. Condensed Results of Conditional Change Regression on SWL at $t_{2}$, Including Interactions (Standard Errors)

\begin{tabular}{lccrr}
\hline & Model 1 & Model 2 & Model 3 & Model 4 \\
\hline $\begin{array}{l}\text { Perceived retirement ritual } \\
\quad \times \text { Perceived competence } t_{1}\end{array}$ & $.08^{* * *}(.02)$ & $.08^{* * *}(.02)$ & $.08^{* * *}(.02)$ & $.08^{* * *}(.02)$ \\
$\quad \times$ Retirement anxiety $t_{1}$ & $.05^{* *}(.02)$ & & $.05^{* *}(.02)$ \\
$\quad \times$ Years retired (centered) & & $.01(.02)$ & $.01(.02)$ \\
Perceived competence $t_{1}$ & & & $-.02^{+}(.01)$ \\
Retirement anxiety $t_{1}$ & $.00(.02)$ & & $-.02^{+}(.01)$ & $-.00(.02)$ \\
Years retired (centered) & & $-.05^{*}(.02)$ & $.04^{*}(.02)$ \\
SWL $t_{1}$ & & & $.07(.06)$ & $.06(.06)$ \\
Constant & $.36^{* * *}(.03)$ & $.36^{* * *}(.03)$ & $.35^{* * *}(.03)$ & $.36^{* * *}(.03)$ \\
$R^{2}$ & $1.69^{* * *}(.15)$ & $1.70^{* * *}(.14)$ & $1.70^{* * *}(.15)$ & $1.76^{* * *}(.16)$ \\
Observations & .331 & .330 & .335 & .341 \\
\hline
\end{tabular}

Note. Controls as in Table 6, model 2. SWL = satisfaction with life. ${ }^{+} p<.10,{ }^{*} p<.05,{ }^{* *} p<.01,{ }^{* * *} p<.001$.

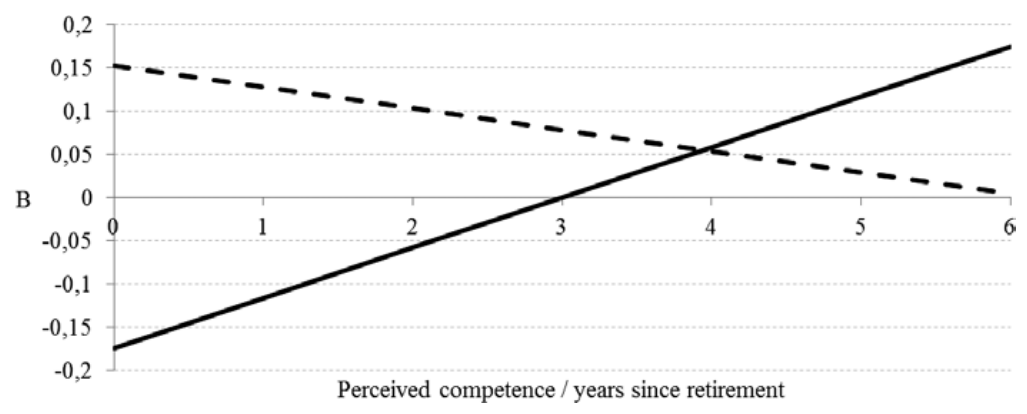

Figure 1. Predicted effect of perceived ritual on satisfaction with life by perceived competence (solid) and years since retirement (dashed), controls as in Table 7. 
Rituals were assessed in two ways: via a subjective evaluation of the ritual, and more objectively via information on the retirement gift. Retirement rituals are interesting because they are a highly understudied topic, and important, given that a growing number of people will be moving into retirement in the near future, and that their well-being is valuable to society as a whole. If attention for departure, in the form of a farewell ceremony or the like, helps to preserve or enhance the life satisfaction of people, then such rituals may be encouraged and supported by employers, employees, and policy makers.

A starting point for the current study was to describe the variables that defined the retirement ritual and how they are related. There appears to be significant variation in the rituals that people experience, with close to half of the retirees in this study feeling that not a lot of effort was put into their farewell ceremony. This was found to be related to the gift that people receive upon their departure: not receiving a souvenir was uncommon, but correlated to a clearly negative evaluation of the retirement ritual, while the involvement of colleagues in selecting and presenting such a gift proved important for a positive assessment. Other factors were also shown to be related to retirement rituals. The experienced extensiveness of the ritual was positively associated with perceived functioning at work and relationships with co-workers, and negatively influenced by involuntary retirement. The latter two factors were similarly associated with the presentation of a gift. Remarkably, neither tenure nor the position at work was found to be of influence for retirement rituals. It seems rituals are more related to the embeddedness at work than to the hierarchal position.

Primarily, this study showed that the experience of a more extensive ritual is associated with higher SWL. This was found most clearly for the subjective experience of the ritual, and limitedly so for the presentation of a gift. The coefficients that were found seemed rather small, with $1 S D$ of difference in the retirement ritual variable related to a difference of about one-tenth of a standard deviation of SWL. Still, given that SWL is a variable that shows great stability within persons over time (Diener et al., 1985), and that any person would likely be interested in raising it through a relatively short and simple ceremony, even if just a little, it can be argued that the associations found are substantial. Further, it could be argued that a pleasant retirement ritual is an echo of a pleasant workplace. Retirement then entails the departure from such a workplace, which may have negative effects on SWL (Wang, 2007), dampening the positive effect of the ritual and thus leading to relatively small effect sizes.

It was also found that a ritual is more important for SWL when people perceived themselves as more professionally competent, but not more important for those who are anxious about their time in retirement. Theoretically, these interactions were based on the idea that retirement rituals look back, recognizing the contributions of the retiree and his or her career, and look forward, inducing confidence for the future. The findings of this study suggest that retirement rituals may be geared more to looking back than looking forward. Given that a significant number of people has questions or worries about their impending retirement and that this is related to lower postretirement SWL, it may be useful to consider more prominently addressing this issue when organizing a retirement ceremony. Furthermore, retirement planning workshops, which may be sponsored by the employer and are perhaps geared more toward life after the cessation of work, may play a consequential role in retirement adjustment. Such types of activities and rituals that relate to the transition of retirement deserve more academic attention.

This study also leads to other new questions. Regarding the data, besides the retirement gift, no information was available on the factual content of the ceremony. A question on the perceived "effort" put into the ritual was used, but it remains unclear to what exactly this effort relates: investments in terms of time, money, or the number of people present. Such information would help to more objectively determine the size and shape of the ritual, and reveal what factors of the ritual are fundamental, and which are more trivial for postretirement wellbeing. In other words, more information on the ritual is necessary to gain understanding about more precisely how retirement rituals may affect people's postretirement life.

As regards representativeness, the selection of respondents for the data was not completely random, and the analytic sample did not include people who moved to so called bridge jobs after retirement. It is conceivable that this has influenced the outcomes, because it may be that these people worked in specific environments or jobs and experienced different kinds of retirement rituals that lead to them being in bridge employment (Wang, Zhan, Liu, \& Shultz, 2008). Together, this makes it important to interpret the results with proper caution. Also, it is plausible that the Dutch context has shaped the results and that comparable analyses in other countries will show different outcomes.

Another relevant question regards unmeasured variable bias. An unconsidered common cause may lie behind the retirement ritual as well as SWL. Some people, for example, may have certain personality traits which lead them to more positively assess both their retirement ritual and their life in general. With observational data it is impossible to unequivocally establish causality, and this is no different for this study. Although several robustness checks were performed, more conservative tests, on better suited data and in different contexts, are necessary to categorically establish —or refute-effects of retirement rituals on well-being.

Finally, it is important to look into other measures of well-being rather than SWL. The variable used in this study is one of several that can be used to assess subjective well-being. Further, it is somewhat retrospective, asking people to evaluate their life not only at that moment, but also up until that moment. Research has shown that when evaluating periods, people tend to put disproportional weight on peak and end experiences (Fredrickson \& Kahneman, 1993). As a farewell ceremony is likely to at least be an end experience, and also likely to have some retrospective elements, its importance for SWL may be different from other measures of well-being. To gain a complete and profound insight into the possible consequences of retirement rituals, it is necessary to look into different types of well-being outcomes.

Summarizing, this study has added to the literature by providing scarce information on retirement rituals, the factors that shape them, and the influence they have on well-being. It has shown that such rituals may play a consequential role in post-retirement satisfaction with life. Such information is important for employers, employees, and family when considering the arrangement of a farewell ceremony and its content, as well as for policy makers when dealing with the rules and regulations that may surround such ceremonies.

\section{REFERENCES}

Allison, P. D. (1994). Using panel data to estimate the effects of events. Sociological Methods and Research, 23, 174-199. 
Atchley, R. C. (1976). The sociology of retirement. Cambridge, MA: Schenkman Publishing Company.

Commission of the European Union. (2000). The future evolution of social protection from a long-term point of view: Safe and sustainable pensions. Brussels, Belgium: Author.

Crawford, M. P. (1973). Retirement: A rite de passage. The Sociological Review, 21, 447-461.

Damman, M., Henkens, K., \& Kalmijn, M. (2013). Late-career work disengagement: The role of proximity to retirement and career experiences. The Journals of Gerontology, Series B: Psychological Sciences and Social Sciences, 68, 455-463.

Diener, E. (2000). Subjective well-being: The science of happiness and a proposal for a national index. American Psychologist, 55, 34.

Diener, E., Emmons, R. A., Larsen, R. J., \& Griffin, S. (1985). The satisfaction with life scale. Journal of Personality Assessment, 49, 71-75.

Dingemans, E., \& Henkens, K. (2014). Involuntary retirement, bridge employment, and satisfaction with life: A longitudinal investigation. Journal of Organizational Behavior, 35, 575-591.

Euwals, R., de Mooij, R., \& van Vuuren, D. (2009). Rethinking retirement. The Hague, The Netherlands: Centraal Planbureau.

Finkel, S. (1995). Causal analysis with panel data. Thousand Oaks, CA: Sage University Publications.

Fredrickson, B. L., \& Kahneman, D. (1993). Duration neglect in retrospective evaluations of affective episodes. Journal of Personality and Social Psychology, 65, 45.

Ganzeboom, H. B. G., de Graaf, P. M., \& Treiman, D. J. (1992). A standard international socio-economic index of occupational status. Social Science Research, 21, 1-56.

Greenfield, E. A., \& Marks, N. F. (2004). Formal volunteering as a protective factor for older adults' psychological well-being. The Journals of Gerontology, Series B: Psychological Sciences and Social Sciences, 59, s258-s264.

Henkens, K., \& Leenders, M. (2010). Burnout and older workers' intentions to retire. International Journal of Manpower, 31, 306-321.

Hershey, D. A., \& Henkens, K. (2014). Impact of different types of retirement transitions on perceived satisfaction with life. The Gerontologist, 54, 232-244.

Inglehart, R. (2002). Gender, aging, and subjective well-being. International Journal of Comparative Sociology, 43, 391-408.

Jacobson, D. (1996). Celebrating good-bye: Functional components in farewell parties for retiring employees in Israel. Journal of Aging Studies, 10, 223-235.

Kapteyn, A., Smith, J. P., \& Van Soest, A. (2010). Life satisfaction. In E. Diener, J. F. Halliwell, \& D. Kahneman (Eds.), International differences in well-being (pp. 70-104). New York, NY: Oxford University Press.

Maddox, G. L. (1968). Retirement as a social event in the United States. In B. Neugarten (Ed.), Middle age and aging (pp. 357-365). Chicago, IL: University of Chicago Press.

Manheimer, R. J. (1994). The changing meaning of retirement. Creative Retirement, 1, 44-49.
Oishi, S. (2010). Culture and well-being: Conceptual and methodological issues. In E. Diener, J. Helliwell, \& D. Kahneman (Eds.), International differences in well-being (pp. 34-69). New York, NY: Oxford University Press.

Pavot, W., \& Diener, E. (1993). Review of the satisfaction with life scale. Psychological Assessment, 5, 164.

Pickering, W. S. (1974). The persistence of rites of passage: Towards an explanation. British Journal of Sociology, 25, 63-78.

Pinquart, M., \& Schindler, I. (2007). Changes of life satisfaction in the transition to retirement: A latent-class approach. Psychology and Aging, 22, 442-455.

Savishinsky, J. S. (1995). The unbearable lightness of retirement: Ritual and support in a modem life passage. Research on Aging, 17, 243-259.

Savishinsky, J. S. (2000). Breaking the watch: The meanings of retirement in America. New York, NY: Cornell University Press.

Schaufeli, W. B., \& van Dierendonck, D. (2000). UBOS Utrechtse Burnout Schaal: Handleiding [UBOS Utrecht Burnout Scale: Manual]. Lisse, The Netherlands: Swets Test Publishers.

Siermann, C., \& Dirven, H.-J. (2005). Uitstroom van ouderen uit de werkzame beroepsbevolking [Exit of older workers from the labor force]. Sociaal Economische Trends, 32-36.

Turner, V. (1969). The ritual process: Structure and anti-structure. New York, NY: Aldine de Gruyter.

Turner, V. (1987). Betwixt and between: The liminal period in rites of passage. In L. C. Mahdi, S. Foster, \& M. LIttle (Eds.), Betwixt \& between: Patterns of masculine and feminine initiation. Peru, IL: Open Court Publishing Company.

van den Bogaard, L., Henkens, K., \& Kalmijn, M. (2016). Retirement as a relief? The role of physical job demands and psychological job stress for effects of retirement on self-rated health. European Sociological Review, 32, 295-306.

van Gennep, A. (1960). The rites of passage. Chicago, IL: University of Chicago Press.

van Solinge, H., \& Henkens, K. (2008). Adjustment to and satisfaction with retirement: Two of a kind? Psychology and Aging, 23, 422-434.

Veenhoven, R. (1993). Happiness in nations. Subjective appreciation of life in 56 nations 1946-1992. Rotterdam, The Netherlands: Erasmus University.

Wang, M. (2007). Profiling retirees in the retirement transition and adjustment process: Examining the longitudinal change patterns of retirees' psychological well-being. Journal of Applied Psychology, 92, 455-474.

Wang, M., Zhan, Y., Liu, S., \& Shultz, K. S. (2008). Antecendents of bridge employment: A longitudinal investigation. Journal of Applied Psychology, 93, 818-830.

Weiss, R. S. (2005). The experience of retirement. New York, NY: Cornell University Press.

Westerlund, H., Kivimäki, M., Singh-Manoux, A., Melchior, M., Ferrie, J. E., Pentti, J., ... Zins, M. (2009). Self-rated health before and after retirement in France (GAZEL): A cohort study. The Lancet, 374, 1889-1896. 